\title{
Brazilian Sign Language: Analysis of its Inclusion in the Training of Nursing Professionals
}

\begin{abstract}
Ana Karla Bezerra da Silva Lima ${ }^{1}$ Danielle Aurília Ferreira Macêdo Maximino², Ester Missias Villaverde Antas ${ }^{3}$, Carlos Bezerra de Lima ${ }^{4}$, Nereide de Andrade Virgínio ${ }^{5}$ Cláudia Germana Virgínio de Souto ${ }^{6}$, Carlos Bezerra de Lima Júnior? Rossana de Roci Alves Barbosa ${ }^{8}$, Daniel Sarmento Bezerra9, Iolanda Beserra da Costa Santos ${ }^{10}$, Lídia Pinheiro da Nóbrega ${ }^{11}$
\end{abstract}

\section{Abstract}

Objective: To assess the need for the Brazilian Sign Language - LIBRAS in the formation of nursing professionals.

Method: Descriptive, exploratory research with quantitative approach, carried out in the Hospital Complex of Infectious and Contagious Diseases Dr. Clementino Fraga in João Pessoa-Paraíba Brazil. The study population consisted of 252 nursing professionals and the sample, of 50 of them. For collecting the data, a structured form was applied in March and April 2015. The data were grouped and distributed in tables containing absolute numbers and percentages, and analyzed in the light of the relevant literature.

Results: $42 \%$ of professionals have attended deaf people, of which $38 \%$ could not read, $43 \%$ of them were unaccompanied, and $68 \%$ of the respondents had no knowledge of LIBRAS.

Conclusion: Everybody recognizes the importance of this knowledge in professional communication with the deaf, and suggests its inclusion in the training of nursing staff and training and qualifying employees.

Communication; Qualification; Nursing.
1 Nurse. Specialist in POUNDS Faculty Montenegro. Professor of Integrated Faculties of Patos, Patos, PB, Brazil.

2 Nurse. Specialist in Family Health. Professor at the New School of Medicine Hope. FAMENE, João Pessoa, $\mathrm{PB}$, Brazil.

3 Nurse. Specialist in Intensive Care Unit. Member of the Group of Study and Research in Wound Care, GEPEFE the Federal University of Paraíba. UFPB, João Pessoa, PB, Brazil.

4 Nurse. PhD in Nursing from UFRJ. Professor of Integrated Faculties of Patos, Paraiba, Patos, Brazil.

5 Nurse. Master in Nursing UFPB. Professor at the New School of Medicine Hope. FAMENE, João Pessoa, $\mathrm{PB}$, Brazil.

6 Nurse. Specialist in Methodology of Higher Education by FACENE. Professor at the New School of Medicine Hope. FAMENE, João Pessoa, PB, Brazil.

7 Philosopher. Master in Philosophy from the Federal University of Paraíba. UFPB, João Pessoa, PB, Brazil.

8 Psychologist. Master's Degree in Family Health for New Hope Nursing Faculty, FACENE.

9 Undergraduate Medicine Faculty of Medicine New Hope. FAMENE, João Pessoa, PB, Brazil.

10 1Nurse. PhD in Health Sciences from UFPB. Professor at the Federal University of Paraíba. UFPB, João Pessoa, PB, Brazil.

11 Biomedical. Specialist in Clinical Microbiology by FIP. Professor of Integrated Faculties of Patos. FIP, Patos, PB, Brazil.

Contact information:

Lídia Pinheiro da Nóbrega.

”"lidiapinheiro03@gmail.com 


\section{Introduction}

People with hearing loss have a typical way of communication, which, in the absence of speech, is full of gestures and noises, and may cause estrangement. Such estrangement may be the beginning of a discrimination, since, not so rare, one would ignore them, avoiding the situation felt as strange and that can generate constraint as the person does not know how to communicate [1]. In the past, the exclusion of deaf people was even greater. They were not allowed to enter the labor market and this was due to both lack of preparation of the deaf as the employment institutions. Throughout time, they have been experiencing many social changes that led to the creation of laws governing, for example, the opening of vacancies for disabled people in public tenders and selection processes. However, this development is still far from the expected and desired by all those who need to be interacting with others in society to which they belong, mainly having their citizenship rights respected [2].

Currently, there is much talk of social inclusion, in order to ensure the improvement of society and, specifically in Brazil, in order to effect the principles of universality of rights and access to goods and services as stated in Article 5 of Federal Constitution in force [3]. Social inclusion implies the development of actions to promote the individual in its entirety, covering the various spheres of his/her life story, and involves the implementation of strategies that can confer benefits to promote individual and collective quality of life.

In the particular case of Brazil, the disclosure of the National Health Survey data - PNS on people with temporary or permanent, progressive, regressive, or stable and continuous or intermittent disabilities. There was estimation of data on four types of disabilities: intellectual, physical, auditory and visual. The PNS estimated 200.6 million people living in permanent private households in 2013. Of this total, $6.2 \%$ had at least one of the four disa- bilities previously mentioned. And that $1.1 \%$ of the country's population had hearing impairment, with the smallest proportion of this indicator observed in the North $(0.8 \%)$ and the highest, in the South (1.4\%).

In the same year, $20.6 \%$ of the hearing-impaired population showed intense or very intense degree of limitations or could not perform the usual activities. And $8.4 \%$ of the Brazilian population with hearing impairment attended a rehabilitation service [4]. The data presented by IBGE reverberate in a serious public health problem, especially in communication between health professionals and the deaf person or with some degree of deafness.

In this context, we can understand that the communication between health professional and the patient without hearing problems occurs, as a rule, in a verbal-auditory form, which does not occur with deaf patient who uses a space-visual language to express his/her feelings, ideas, wills, among others. Therefore, the signs are made in space, using the body and hands, and raised by the eyes, which together form a language recognized by the linguistics as natural deaf, and not as a language pathology [5].

To the detriment of the magnitude of this essential communication tool for deaf people, Law No. 10.436 of April 242002 comes to recognize the Brazilian Sign Language - LIBRAS as legal means of communication and expression with its own grammatical structure, due to the fact that this language conveys the ideas and facts through their visual-motor linguistic system, emphasizing that this system originated from the communities of deaf people in Brazil [6].

In this sense, the sign language enables the communication between the professional and the deaf person under his/her care and, thus, promotes a quality care, with resoluteness and universal access of deaf people to health services such as hospitals, clinics, family health units (PSF), the emergency units (UPA), among others [5-6]. 
Therefore, those people have, throughout their lives, a history of hard struggle to ensure their place in society, to be recognized as human beings, and to enjoy the same citizenship rights as other socalled normal people.

This fight has just begun in the early days of mankind, remains in current days and gains a voice in what we call "social inclusion". When we talk about social inclusion of those people, it is not limited to equal opportunities; it also requires the availability of specific resources, adjustments, adaptations and support. People with disabilities, as well as others, are entitled to inclusion in different social environments and a quality life with access to inclusive and accessible education, in addition to quality care and health. In the health context, the LIBRAS between the hearing impaired and nurses can be used as a means of social inclusion and humanization of care provided by the professional, in addition to facilitating the recognition of signs and symptoms of the deaf person to provide subsidies for a correct diagnosis [7].

Based on the above, the following question arose: how are nursing professionals facing the problem of communication with the deaf person nowadays? Is this professional aware of the of Law No. 10,436/2002 and Decree No. 5,626/2005 that create and regulate the use of Brazilian Sign Language - LIBRAS, and, with it, many other rights such as personal and quality service in the health sector, just as people who do not have hearing problems have?[6-8].

Thus, in view of the addressed issues, the objectives of this study were to assess the need for the Brazilian Sign Language - LIBRAS in the formation of nursing professionals, to characterize the social profile of the study participants, to determine the establishment of communication between the deaf person and nursing professionals, to evaluate the effectiveness of communication between the nursing professional and the deaf person in the hospital context, to identify the knowledge of nurses about the Law 10,436/2002 and Decree 5,626/2005 and its obligation [6-8].

Therefore, this context justifies the development of this study. Its development occurs with the expectation to raise the issue of the need for a solution for the communication block between health professional and patient, which will come with the inclusion of the LIBRAS in the formation of nursing professionals, and observing the requirement of Law No. 10,436/2002 and the Decree No. 5,626/2005, as well as with the purpose of deepening the knowledge that we hold about the need for communication between health professionals and the deaf person [6-8].

\section{Methods}

This study characterizes as a descriptive and exploratory research, developed by a quantitative approach. Exploratory research aims to identify and build hypotheses that can be useful in future studies [9]. As regards the quantitative approach, it characterizes as the use of quantification of both informationgathering methods, as their treatment by means of statistical techniques from the simplest ones, such as percentage, mean, standard deviation, to the most complex, such as correlation coefficient, regression analysis, etc. [10].

The research had as scenario for its development the Hospital Complex of Infectious and Contagious Diseases Dr. Clementino Fraga, located in João Pessoa, Paraíba, Brazil. It is a medium-sized hospital, a reference in the treatment of infectious diseases such as HIVIAIDS, tuberculosis, leprosy and hepatitis $B$ and $C$, serving patients from all over the state of Paraiba. They arrive at the hospital, are received, undergo screening, examinations, are diagnosed and referred to the corresponding sector, according to their need for health.

We chose the Clementino Fraga as the location for this research, because it is an institution that serves a very large daily demand of patients, being 
deaf people also part of such public user of the health services, as reports of its nursing professionals. The study population consisted of 96 nurses and 156 technicians who are part of the institution workforce, amounting to 252 professionals of the nursing team. The hospital nursing management provided that quantity. The sample consisted of 50 of those professionals.

The inclusion criteria to choose the participants in the study were: being a nurse or nursing technician and freely agreeing to participate in the study by signing the Informed Consent Form - ICF. Nursing assistants, interns and volunteers present at the institution were excluded from the study.

A questionnaire containing objective questions was the instrument to collect data, applied to the participants in the study by the researcher. The form, while data collection technique, is between the questionnaire and the interview. Therefore, its proper application requires recommendations in its preparation and the interview condition. Its application consists of the most appropriate techniques for data collection, for the researcher, besides being present, is the one who makes the previously prepared questions and records the answers. However, due to its characteristics, the form has limited range, not allowing data acquisition in greater depth [9].

The data collection was formalized with the approval by the Ethics Committee of the College of Nursing Nova Esperança (FACENE), as certificate issued under No. 028/2015 and protocol CAAE 42026915.3.0000.5179, respecting the following steps: 1) Contact with the direction/coordination of the Hospital Complex of Infectious Diseases Dr. Clementino Fraga; 2) Contact with nurses and nursing technicians to schedule the interviews; 3) After those steps, the data collection occurred in March and April 2015.

The survey was conducted on weekdays, from Monday to Friday, when were explained the research objectives and its importance, as well as the presentation of the Informed Consent Form -
ICF, duly signed. The data were analyzed using a quantitative approach. In relation to the quantitative analysis, it has a type of conceptual objectivity and validity, which contributes decisively to the development of scientific thinking; it turns opinions and information into numbers, through statistical techniques to classify and analyze them [11]. In this sense, the data were grouped and distributed in the form of tables that contain frequencies and percentage, and discursively analyzed, in the light of the relevant literature.

This research was conducted based on the ethical aspects of research involving human subjects, recommended by Resolution 466/12, CNS, ethical aspects dealing with the involvement of human beings in research, in particular Article $V$, of the risks and benefits, which highlights that all human research involves risk in varied types and gradations, and that, the greater and more obvious the risks, the greater must be the care to minimize them and the protection offered by the CEP/CONEP to participants [12].

As well as the governing resolution 311/2007 of the Federal Council of Nursing (COFEN), which deals with the ethics code of nursing professionals. It determines, in Article 90, that one must interrupt the research in the presence of any danger to life and integrity of the person, and reinforces, in Article 91, the respect for the principles of honesty and trustworthiness, as well as the copyright in the research process, especially in the dissemination of its results [13].

In this regard, it is noteworthy that the research may present a psychological risk, since some professionals may feel embarrassed at the time that this study evaluates their knowledge about the Law and the Decree in question. Nevertheless, its benefits outnumber the risks to the extent that this study aims to contribute to a better qualification of nursing professionals. 


\section{Results}

\section{Sample characterization}

Table 1 presents the characteristics of nurses and nursing technicians who participated in the study with 50 professionals, according to the socioeconomic and professional aspects. Considering the age of the survey participants, $30 \%$ are over 50 years old, which means 15 participants. Then, we have the age groups from 31 to 35 , with $20 \%$ of participants.

Table 1. Sample distribution $(n=50)$ according to the socioeconomic and professional characterization of the study participants. João Pessoa/PB, 2015.

\begin{tabular}{|c|c|c|}
\hline Variable & $\mathrm{n}$ & $\%$ \\
\hline \multicolumn{3}{|l|}{ Age Group (years) } \\
\hline $20-25$ & 01 & 02 \\
\hline $26-30$ & 05 & 10 \\
\hline $31-35$ & 10 & 20 \\
\hline $36-40$ & 07 & 14 \\
\hline $41-45$ & 04 & 08 \\
\hline $46-50$ & 08 & 16 \\
\hline Above 50 & 15 & 30 \\
\hline \multicolumn{3}{|l|}{ Education } \\
\hline Complete High School & 21 & 42 \\
\hline Graduation & 13 & 26 \\
\hline Specialization & 16 & 32 \\
\hline \multicolumn{3}{|c|}{ Time working at this hospital (years) } \\
\hline$<01$ & 04 & 08 \\
\hline $01-03$ & 09 & 18 \\
\hline 04-05 years & 08 & 16 \\
\hline 06-10 years & 15 & 30 \\
\hline Above 10 & 14 & 28 \\
\hline \multicolumn{3}{|l|}{ Position at the institution } \\
\hline Nursing Technician & 28 & 56 \\
\hline Nurse & 22 & 44 \\
\hline \multicolumn{3}{|c|}{ Type of work contract with the institution } \\
\hline Gazetted & 32 & 64 \\
\hline Service Provider & 18 & 36 \\
\hline Total & 50 & 100 \\
\hline
\end{tabular}

Source: Direct survey with nurses and nursing technicians, 2015
As for education, we identified that $42 \%$ of participants completed high school, a total of 21 professionals, and, despite being outnumbered, this research had thirteen professionals with only graduation and sixteen specialized professionals, accounting for 29 professionals with higher education (specialists or not), $58 \%$ of respondents. When we treat the position at the institution, we collected the numbers: $56 \%$ of participants are nursing technician, which means 28 professionals, and 44\% are nurses - 22 individuals.

Brazilian nursing is the largest workforce in the health sector, and there were 32 gazetted employees, representing 64\%; in relation to service providers, there were 18 individuals, $36 \%$ of respondents [14]. We also emphasize that, regarding the time working at the institution, 30\% of the professionals had been working at the hospital for six to ten years; $28 \%$ of our sample had been working for more than ten years.

We found, in Table 2, that $42 \%$ of the participants, 21 professionals, have already had the opportunity to serve or care for deaf patients. Among those 21 professionals, 47\% (10 participants) have already performed this service more than five times

Table 2. Sample distribution $(n=50)$ according to the opportunity of taking care of deaf people. João Pessoa/PB, 2015.

\begin{tabular}{|l|l|l|}
\hline \multicolumn{1}{|c|}{ Variable } & $\mathbf{n}$ & $\%$ \\
\hline Opportunity of serveing a deaf person & & \\
\hline Yes & 21 & 42 \\
\hline No & 29 & 58 \\
\hline Number of services to the deaf $(n=21)$ & & \\
\hline Once & 03 & 14 \\
\hline Twice & 06 & 29 \\
\hline 3 times & 01 & 05 \\
\hline 4 times & 01 & 05 \\
\hline$>5$ times & 10 & 47 \\
\hline The deaf patient could read and write $(n=21)$ & \\
\hline Yes & 09 & 43 \\
\hline No & 08 & 38 \\
\hline Some could; others could not & 04 & 19 \\
\hline
\end{tabular}




\begin{tabular}{|l|c|c|}
\hline \multicolumn{1}{|c|}{ Variable } & $\mathbf{n}$ & $\%$ \\
\hline The deaf patient had a listener companion & $(\mathrm{n}=21)$ & \\
\hline Yes & 11 & 52 \\
\hline No & 09 & 43 \\
\hline Some had; other had not & 01 & 05 \\
\hline Form of communication established with the deaf & $(\mathrm{n}=21)$ \\
\hline By signs (gestures) & 12 & 57 \\
\hline By writing & 03 & 14 \\
\hline With the help of na interpreter (someone & 04 & 19 \\
\hline who understands the person) & 02 & 10 \\
\hline By signs (gestures) and writing & 21 & 100 \\
\hline Total & &
\end{tabular}

Source: Direct survey with nurse and nursing technicians, 2015.

and $29 \%$ (six participants), held two services or care for deaf patients.

The most used form of communication between the nursing professional and deaf was by gestures or signs. Not the signs used in LIBRAS, but rudimentary gestures in the form of mimicry, representing $57 \%$ (12) of the participants. In only 19\% (four) of cases, the deaf had someone to interpret the Portuguese for him/her. That is, the other remaining $81 \%$ could or would rather be alone, thinking they would receive proper health treatment as recommended by the current legislation [8].

In the study, 52\% (11) of participants, the patient had a listener companion, and 43\% (nine) of the cases had no companion. This confirms the certainty of the deaf that he/she will receive the appropriate care regarding his/her special conditions. The worse part is that 38\% (eight) of participants reported serving deaf people who could not read or write; only $43 \%$ (nine) of the professionals reported attending deaf people who could read and write. In the case the deaf patient is alone, we can consider writing a means of communication.

Sixteen professionals (52\%) responded positively regarding if they knew the legislation. However, among them, only four professionals $(25 \%)$ said it was something about the right of deaf people; five (32\%) participants stated it was something related to social inclusion, and seven (43\%) participants "did not remember".
Table 3. Sample distribution $(n=50)$ according to the knowledge of nursing professionals regarding the LIBRAS legislation - Law No. 10,436/2002 and Decree No. 5,626/2005. João Pessoa/PB, 2015.

\begin{tabular}{|c|c|c|}
\hline Variable & n & $\%$ \\
\hline \multicolumn{3}{|c|}{$\begin{array}{l}\text { Knowledge of the nursing professional about de LIBRAS } \\
\text { legislation }\end{array}$} \\
\hline Yes & 16 & 32 \\
\hline No & 34 & 68 \\
\hline Total & 50 & 100 \\
\hline \multicolumn{3}{|c|}{$\begin{array}{l}\text { The knowledge stated by the health professional on the } \\
\text { mentioned Legislation }(n=16)\end{array}$} \\
\hline The deaf people's rights & 04 & 25 \\
\hline Social inclusion & 05 & 32 \\
\hline Do not remember & 07 & 43 \\
\hline Total & 16 & 100 \\
\hline \multicolumn{3}{|c|}{$\begin{array}{l}\text { The LIBRAS Legislation focuses on certain professionals } \\
\text { classes, according to the health professional }(n=16)\end{array}$} \\
\hline Government & 03 & 19 \\
\hline Health and Education Professionals & 03 & 19 \\
\hline Do not know & 10 & 62 \\
\hline Total & 16 & 100 \\
\hline
\end{tabular}

Source: Direct survey with nurses and nursing technicians, 2015.

In the same Table 3, when we also asked if the same professional was aware of the obligatoriness of that legislation and its target public, only three (19\%) said it was for health and education professionals, who are responsible for putting the Law No. 10,436/2002 and Decree No. 5,626/2005 into practice, and other three stated it was for the Government, ten (62\%) participants had no idea [6-8].

We asked the nursing professional about the importance of establishing effective communication with deaf people and suggestions for its effectiveness, and got numbers well within expectations. In our research with 50 nursing professionals, 100\% of participants judged important the Brazilian Sign Language (LIBRAS) in communication between the nursing professional and the deaf person. Hence, $44(88 \%)$ professionals who participated in the survey said they agreed with the importance of the 
LIBRAS as an obligatory discipline in the graduation of nursing professionals

This research was carried out at a hospital with nursing professionals who are already working, away from the classrooms where they acquired their training. We then asked, in Table 4, what would be their suggestion to improve their communication with deaf patients, and 41 (82\%) responded qualification and training for the employees, followed by five (10\%), who suggested that LIBRAS should be included in the college curriculum of nursing technicians and nurses.

Table 4. Sample distribution $(n=50)$ according to the importance of establishing the communication with the deaf person and suggestions for its effectiveness. João Pessoa/PB, 2015.

\begin{tabular}{l|c|c|}
\multicolumn{1}{|c|}{ Variable } & F & $\%$ \\
\hline \begin{tabular}{l|c|}
\hline Importance of the LIBRAS in the communication between \\
the nursing professional and the deaf person
\end{tabular} \\
\hline Yes & 50 & 100 \\
\hline $\begin{array}{l}\text { Importance of the LIBRAS as an obligatory discipline in the } \\
\text { graduation of the nursing professional }\end{array}$ & 44 & 88 \\
\hline Yes & 06 & 12 \\
\hline No & 41 & 82 \\
\hline $\begin{array}{l}\text { Suggestion of the nursing professional to improve the } \\
\text { communication with the deaf person }\end{array}$ & \\
\hline $\begin{array}{l}\text { Qualification and training of the } \\
\text { employees }\end{array}$ & 05 & 10 \\
\hline Part of the college curriculum & 01 & 02 \\
\hline $\begin{array}{l}\text { Each professional must seek } \\
\text { knowledge in isolation }\end{array}$ & 04 & 08 \\
\hline Hire an interpreter & 50 & 100 \\
\hline Total
\end{tabular}

Source: Direct survey with nurses and nursing technicians, 2015.

\section{Discussion}

Recent study results show a large population of young professionals, with their maximum of productive strength, exercise nursing in Brazil. Since they are professionals committed to the ethics of a good development of nursing practice, and present in so many fields and health performance levels, it represents about $49.6 \%$ of the workforce in the health sector, being necessary, thus, to recognize the importance, as well as the need for approaching their profile [14].

However, in this study, table 1 shows that most respondents form a population of professionals whose age is greater than 50 years old. That does not come to be consistent with the reality of the profession reported in academic studies, which state that the professional must be in constant renewal and training, identifying technological transitions, of the social and productive environment [15].

Therefore, the nursing professional, regardless of age, seeks his/her scientific/professional growth and recognizes the need to assimilate not only technological knowledge and domination of the use of modern equipment, but also to be able to develop virtues and personal qualities that foster autonomy and creativity that will make him/her stand out in the professional environment [15]. In any area, the level of efficiency is measured by combining expertise with a basic culture, consisting of codes and languages, mathematics, humanities and natural sciences, which will ensure greater integration in the world of work and social relations.

When we treat the item position at the institution, $56 \%$ are nurses and $44 \%$, nursing technicians. This is in accordance with Resolution No. 293/2004, which scales the amount of nursing professionals at different levels of training for healthcare coverage in health institutions. In Article 5 of that resolution, we can observe the correct percentage distribution of all nursing professionals that should exist in a health institution, taking into account the group of patients with the highest prevalence to ensure a minimum and intermediate care, semi-intensive and intensive. What we must emphasize is the prevalence of the percentage of nursing technicians over the nurses', according to the same law [16].

The Hospital Clementino Fraga shows, therefore, a different reality from the one we have followed in published studies and researches, such as the official 
journal of the Federal Council of Nursing - COFEN. As an article extracted from the mentioned journal demonstrates, revealing that a mass exodus of nurses towards professional practice has been evident in recent years due to problems related, mainly, to long and repeated days of work in more than one health institution, low wages due to lack of a wage policy for the category, vagueness of their practice by misinformation or submission, the increase, from the 1990s, in mid-level and higher nursing schools, saturating, thus, the labor market, and other social issues [17].

Communication is an essential tool for implementing various procedures in health. Table 2 presents an analysis of how nurses and deaf people have interacted to make such communication, how it is characterized and which relationship resources those professionals have used to carry out such communication [18]. Deaf people tend to isolate and gather in a quiet and single world of their own, where they feel more protected against the listeners' understanding disability. This creates social isolation and, with it, a number of issues, including health. Therefore, the nurse role is essential regarding their orientation.

The orientation begins in nursing consultation, in which the professional who serves a client with hearing loss must first abolish the comparison between deaf and mentally ill and the assignment that they are low-intelligent individuals. Later, the nurse must be competent in the use of non-verbal communication techniques in order to develop an approach that allows the acquisition of knowledge of the issues inherent to a humanized care to all deaf people, in order to offer them support, information and awaken feelings of confidence and self-esteem [19].

Sometimes when they are at the nursing consultation, nursing professionals and deaf patients are not able to establish any link because of the limitations that hinder the communication, since the sign language is often unknown by most health professionals. What some authors suggest is the presence of a LS interpreter as a mediator, which implies the inclusion of a third person in this relationship [18].

Nevertheless, there are some criticism and limitations for the activities of those interpreters in the health area, since their presence during treatment in the nursing consultation can cause or increase the embarrassment, endanger the right of confidentiality and customer privacy, as well as harm quality of the information passed on by the customer or by the nursing professional [20].

When we look at table 3 , we can see that the knowledge of health professionals about the legislation which creates and regulates the Brazilian Sign Language (LIBRAS) - Law No. 10,436/2002 and Decree No. 5,626/2005, disinformation is striking [6 -8]. The nursing professional is not obligated to know all the laws that govern and protect the rights of all persons with disabilities. However, he/she should be informed and acquire knowledge on such laws as it pertains to his/her profession. For it is up to a good professional to seek his/ her improvement and execution of tasks with the greatest possible perfection. And the laws exist for such purpose, guiding people about their obligations and rights.

Law No. 10,436/2002 intends to make the LIBRAS the second official language in our country and, its Article 3, draws the attention of public institutions and health care utilities companies to ensure the care and adequate treatment for the hearing impaired, according to the legal provisions in force [6].

The standards mentioned in the above article appear in Decree No. 5,626 of December 22, 2005, specifically in Articles 25-31, in which the health professional is charged in order to provide a guaranteed and comprehensive assistance to deaf patients as a skilled professional and enabled to use the LIBRAS, knowing its translation and interpretation, since, in the same decree, he/she shall receive training to do so [8]. 
Moreover, Decree No. 5,626/2005, Article 26, first paragraph, states: "The institutions of the caput must have at least five percent of servers, officers and employees trained in the use and interpretation of LIBRAS" [8]. For there would be no other way to make the communication between deaf and nursing professional happen, if not through qualification, training course oreven disciplines included in the curriculum of nursing technicians and nurses.

The result in table 4 proposes a reflection on the context in which there is much discussion regarding accessibility, for it is important to disseminate knowledge about LIBRAS among students of health courses, in order to contribute to the training of professionals capable of understanding and assisting the needs of people who use it as their first language [21]. We obtained the percentage of $88 \%$ of the surveyed professionals, who stated they agreed with the importance of LIBRAS as a compulsory subject in the training of nursing professionals, undoing, thus, the linguistic and cultural barrier that exists between professional and patient, which causes misinformation and hinders relations. Therefore, promoting the expansion of access for deaf patients to health services, will only be truly viable, qualifying and professionalizing, still at the academies, the professionals who shall establish this communication and understand those patients' needs [21].

\section{Conclusion}

Accomplishing this research enabled the achievement of its objectives. It enabled expanding the knowledge that we held about the issues around social inclusion of deaf, particularly as regards the insertion of Brazilian Sign Language (LIBRAS) in the formation of nursing professionals, technicians or graduated. Such conclusion was guided by the lack of knowledge of the professional on the Law 10,436/2002 and Decree 5,626/2005 that determine LIBRAS to be mandatory in the context of health services, as well as the precariousness in the attendance of deaf patients by the lack of an instrument that enables establishing communication with them [6-8].

From those findings, we believe that the inclusion of Brazilian Sign Language in the training of nursing professionals will contribute to the effective communication of those professionals with the deaf, which occurs in a process of interaction in which individuals share messages, knowledge, ideas, feelings and emotions. That is the condition so that the nursing professional can serve properly, identifying the needs of the people he/she assists in view of the principles of problem solving, humanization and comprehensiveness.

The user's needs should guide the assistance provided by the professional within each segment of health services. The demands and the profile of that user should guide the professional regarding how the development of the work to enable a good receptiveness and ensure the humanization of care. However, there is a specialized health care service to the deaf, with trained and qualified professionals to serve this clientele. This study helped us realize that the attendance of deaf patient is weak. This goal is far from being achieved and the communication has been the biggest barrier, preventing its achievement.

Another finding is that LIBRAS is still a foreign language for most health professionals. Laws ensuring a quality service for the deaf patient and/or deafness carrier already exist. Now, it is urgent to socially include those people, especially in health and education. Nevertheless, for this, nursing professionals need to be prepared and aware that the big change must come from them. Establishing communication with a patient who does not listen and, therefore, cannot speak the listener's language is only possible if the listener learns LIBRAS, and not the deaf learns Portuguese. We need to be sensitive to the comprehensiveness to truly realize the humanization with an inclusive mindset. 
It is, therefore, urgent to put in place this new idea: to better qualify nursing professionals being trained in educational institutions of this country. The current social context requires graduating a professional closer to the needs of isolated groups, who knows how to establish an important communication bond between him/her and the special group, which is also part of the society, fully guaranteeing the fulfillment of their needs within the health sector.

\section{References}

1. Ribeiro K. Sexualidade e gênero: estudo das relações afetivas de jovens surdas de uma escola municipal de educação especial de São Paulo. Tese de Doutorado, Faculdade de Educação da Universidade de São Paulo, São Paulo. 2011.

2. Espote R, Serralha CA, Comin FS. Inclusão de surdos: revisão integrativa da literatura científica. Psico-USF. 2013; 18(1): 77-88.

3. Brasil. Constituição Federativa da República do Brasil de 1988.

4. Pesquisa nacional de saúde: 2013: ciclos de vida: Brasil e grandes regiões / Instituto Brasileiro de Geografia e Estatística, Coordenação de Trabalho e Rendimento. - Rio de Janeiro: IBGE, 2015; 92

5. Sacks OW. Vendo vozes: uma viagem ao mundo dos surdos. (Trad.) Laura Teixeira Motta. São Paulo: Companhia das Letras, 2010.

6. Brasil. Dispõe sobre a Língua Brasileira de Sinais - Libras e dá outras providências. Lei $n^{\circ} 10.436$ de 24 de abril de 2002. Brasília, 2002.

7. Trecossi MO, Ortigara EPF. A importância e eficácia das consultas de enfermagem ao paciente surdo. Revista Enferm. 2013; 9 (9):60-9

8. Brasil. Regulamenta a Lei no 10.436, de 24 de abril de 2002, que dispõe sobre a Língua Brasileira de Sinais - Libras, e o art. 18 da Lei no 10.098, de 19 de dezembro de 2000. Decreto $n^{\circ}$ 5.626 de 22 de dezembro de 2005. Brasília, 2005

9. Sampieri RH, Collado CF, Lucio MPB. Metodologia da pesquisa. Mc Graw Hill: Bookman. 5 ed. 2015

10. Freixo MJV. Metodologia Científica- Fundamentos, Métodos e técnica. 4ª ed. Brasil: Instituto Piaget; 2012.

11. Creswell JW. Projeto de pesquisa: métodos qualitativo, quantitativo e misto. $3^{a}$ ed. Porto Alegre: Atmed, 2010

12. Brasil. Ministério da Saúde. Conselho Nacional de Saúde. Resolução n 466 de 12 de dezembro de 2012. Brasília, 2012.

13. Conselho Federal de Enfermagem- COFEN. Código de ética dos profissionais de enfermagem. Resolução n³11/2007. Rio de Janeiro, 2007.
14. Barreto IS, Krempel MC, Humerez DC. O COFEN e a enfermagem na América Latina. Rev Enferm Foco. 2011; 2 (4): 251-54.

15. Manzato $C R U$, Ribeiro $M L$, Araújo DS. A trajetória da educação profissional do auxiliar e técnico em enfermagem. Rev Uniara. 2012; 15 (2): 27-39.

16. Brasil. Conselho Federal de Enfermagem-COFEN. Dimensionamento da enfermagem. Resolução n² 293/2004. Rio de Janeiro, 2004.

17. Villela LCM, Galastro EP, Freitas MEA, Santos MSG, Notaro KAM. Tempo de atuação do profissional enfermeiro. Rev Enferm Foco. 2012; 2 (4): 248-50.

18. Chaveiro N, Barbosa MA, Porto CC, Munari DB, Medeiros M, Duarte SBR. Atendimento à pessoa surda que utiliza a língua de sinais, na perspectiva do profissional da saúde. Cogitare Enferm. 2010; 15(4): 639-45.

19. Araújo CCJ. Consulta de enfermagem às pessoas surdas: uma análise contextual. Trabalho de conclusão de curso (Graduação de enfermagem)- Universidade Estadual da Paraíba, Centro de Ciências Biológicas da Saúde, 2013.

20. Oliveira YCA, Costa GMC, Coura AS, Cartaxo RO, França ISX. A língua brasileira de sinais na formação dos profissionais de enfermagem, fisioterapia e odontologia no estado da Paraíba, Brasil. Interface- Comunic Saúde Educ. 2012; 16 (43): 995-1008.

21. Levino DA, Souza EB, Cardoso PC, Silva AC, Carvalho AETM. LIBRAS na graduação médica: o despertar para uma nova língua. Rev Bras Educ Médica. 2013; 37 (2): 291-297.

\section{Publish in International Archives of Medicine}

International Archives of Medicine is an open access journal publishing articles encompassing all aspects of medical science and clinical practice. IAM is considered a megajournal with independent sections on all areas of medicine. IAM is a really international journal with authors and board members from all around the world. The journal is widely indexed and classified Q2 in category Medicine. 